\title{
Effect of Health Promotion with Audiovisual on Knowledge of the Use of Personal Protective Equipment for Covid-19 in Health Workers \\ Pengaruh Promosi Kesehatan dengan Audiovisual terhadap Pengetahuan Penggunaan Alat Pelindung Diri Covid-19 pada Tenaga Kesehatan
}

\author{
Christine T. Siwi, ${ }^{1}$ Suryadi N. N. Tatura, ${ }^{2}$ Jimmy Posangi ${ }^{3}$
}

\author{
${ }^{1}$ Program Pascasarjana Universitas Sam Ratulangi, Manado, Indonesia \\ ${ }^{2}$ Bagian Ilmu Kesehatan Anak Fakultas Kedokteran Univeristas Sam Ratulangi, Manado, \\ Indonesia \\ ${ }^{3}$ Bagian Farmakologi Fakultas Kedokteran Universitas Sam Ratulangi, Manado, Indonesia \\ Email: christinesiwi1111@ student.unsrat.ac.id \\ Received: November 13, 2021; Accepted: January 26, 2022; Published on line: January 28, 2022
}

\begin{abstract}
Health workers are very risky to be infected by Covid-19 virus. The use of personal protective equipment (PPE) for Covid-19 can minimize the transmission of Covid-19. This study was aimed to determine the effect of audio-visual health promotion on knowledge of the use of Covid-19 PPE among health workers. This was a pre-experimental study waith one-grup pre test post test design. Data were analyzed univariately as well as bivariately with paired t-test. Respondents were 40 health workers at the Ratahan Health Center, Southeast Minahasa Regency. The activity was started by signing the approval for filling out questionnaires, doing the pretest, then audiovisual health promotion intervention was carried out and continued with filling out the questionnaire posttest. The results showed that before the health promotion about Covid-19 PPE, most respondents had lack of knowledge as many as 35 health workers $(87.5 \%)$ and after the health promotion was carried out the knowledge of health workers was categorized as good, namely 36 health workers $(90 \%)$. The paired t-test showed tat the average value of health worker knowledge before the health promotion about Covid-19 PPE was 22.48 \pm 1.5 , and after the health promotion the knowledge of health workers was increased to $34.0 \pm 0.0$ with a p-value of 0.0 . In conclusion, the audiovisual health promotion about Covid-19 PPE increases the knowledge of health workers. Keywords: personal protective equipment (PPE); health workers; health promotion
\end{abstract}

\begin{abstract}
Abstrak: Tenaga kesehatan (nakes) sangat berisiko terhadap terinfeksi oleh virus Covid-19. Penggunaan alat pelindung diri (APD) Covid-19 dapat meminimalisir penularan Covid-19. Penelitian ini bertujuan untuk mengetahui pengaruh promosi kesehatan dengan audiovisual terhadap pengetahuan penggunaan APD Covid-19 pada nakes. Jenis penelitian ialah preeksperimental dengan one-grup pre test post test design. Analisis data menggunakan analisis univariat dan analisis bivariat dengan uji paired t-test. Responden penelitian ini sebanyak 40 nakes di Puskesmas Ratahan, Kabupaten Minahasa Tenggara. Kegiatan dimulai dengan menandatangani persetujuan pengisian kuesioner pretest kemudian dilakukan intervensi promosi kesehatan menggunakan audiovisual, dan dilanjutkan dengan pengisian kuesioner posttest. Hasil penelitian mendapatkan bahwa sebelum diberikan promosi kesehatan tentang APD Covid-19 pengetahuan nakes terbanyak berada pada kategori kurang yaitu 35 orang $(87,5 \%)$ dan setelah diberikan promosi kesehatan pengetahuan nakes berada pada kategori baik yaitu 36 orang (90\%). Hasil analisis bivariat dengan uji paired t-test menunjukkan nilai rerata pengetahuan nakes sebelum diberikan promosi kesehatan sebanyak $22,48 \pm 1,5$ dan setelah diberikan promosi kesehatan pengetahuan nakes meningkat sebanyak $34,0 \pm 0,0$ dengan nilai $\mathrm{p}=0,0$. Simpulan penelitian ini ialah promosi kesehatan dengan audiovisual tentang APD Covid-19 berpengaruh dalam meningkatkan pengetahuan tenaga kesehatan.
\end{abstract}

Kata kunci: alat pelindung diri (APD); tenaga kesehatan; promosi kesehatan 


\section{PENDAHULUAN}

Corona virus merupakan keluarga besar virus yang dapat menyebabkan penyakit mulai dari gejala ringan sampai berat. Terdapat dua jenis corona virus yang diketahui menyebabkan penyakit yang dapat menimbulkan gejala berat seperti Middle East Respiratorty Syndrome (MERS) dan Severe Acute Respiratory Syndrome (SARS). Novelcorona virus, disingkat 2019-nCoV, pertama kali diidentifikasi di tengah merebaknya kasus penyakit infeksi paru atau pneumonia di kota Wuhan, Provinsi Hubei, Cina. Penyakit infeksi ini dinyatakan sebagai keadaan darurat dunia (pandemi) atau global outbreak oleh World Health Organization (WHO) pada tanggal 30 Januari 2020 dan disebut sebagai Covid-19 (Corona Virus Diesase19). Peta penyebaran virus ini telah terjadi di banyak negara di luar China., ${ }^{1,2}$

Pelayanan publik merupakan kegiatan atau rangkaian kegiatan dalam rangka pemenuhan kebutuhan pelayanan sesuai dengan peraturan perundang-undangan bagi setiap warga negara dan penduduk atas barang jasa atau pelayanan administratif yang disediakan oleh penyelenggara. Termasuk di dalamnya pelayanan kesehatan bagi masyarakat dengan berbagai macam penyakit salah satunya infeksi virus, mulai dari gejala ringan sampai berat, penularan infeksi tersebut dapat melalui beberapa cara di antaranya melalui udara, darah, dan cairan tubuh. Pekerjaan di bidang medis sangat berisiko terhadap kecelakaan yang dapat mengakibatkan tenaga kesehatan terinfeksi oleh virus akibat minimnya kesadaran dan kepatuhan dalam penggunaan APD di situasi pandemi seperti ini yang dapat mengganggu kesehatan terhadap tenaga kesehatan. ${ }^{3}$ Salah satu kelompok yang paling berisiko terkena penyakit infeksi, termasuk Covid-19 ialah tenaga kesehatan atau petugas medis baik dokter, perawat, maupun petugas medis lain yang sering berkontak dengan pasien Covid-19. Oleh karena itu, para tenaga kesehatan perlu menggunakan APD sesuai standar agar mereka terlindungi dari infeksi virus Covid-19. ${ }^{4-6}$

Pada masa pandemi Covid-19 ini, penggunaan APD sangat penting untuk menurunkan risiko penularan penyakit infeksi pada tenaga kesehatan agar dapat menghindari kontak dengan patogen. Terdapat banyak hal yang harus selalu dipatuhi oleh tenaga kesehatan terkait APD yaitu antara lain cara melepaskan APD dan meningkatkan kepatuhan tenaga medis dalam menggunakan APD. ${ }^{3}$ Penelitian oleh Ningsih $^{4}$ terhadap tenaga kesehatan di Ruang Rawat Inap Rumah Sakit Umum Daerah Palembang mendapatkan bahwa perilaku penggunaan APD oleh tenaga kesehatan tidak bermakna, ditunjukkan dengan mayoritas responden memiliki perilaku penggunaan APD kurang patuh yang berjumlah 44 tenaga kesehatan $(52,4 \%)$. Berbeda halnya dengan studi pendahuluan oleh Pangastuti ${ }^{7}$ di RS PKU Muhammadiyah Yogyakarta Unit II terhadap responden tenaga kesehatan yang mendapatkan hasil sangat baik. Pada variabel kepatuhan diperoleh sebanyak 21 tenaga kesehatan $(70 \%)$ patuh, dan sembilan tenaga kesehatan $(30 \%)$ tidak patuh yang menyimpulkan bahwa kepatuhan tenaga kesehatan tentang penggunaan APD sebagian besar ialah patuh.

Berdasarkan survei awal yang dilakukan di Puskesmas Ratahan Kabupaten Minahasa Tenggara terdapat banyak tenaga kesehatan yang lalai dalam penggunaan APD, dan ditemukan tujuh dari sepuluh tidak memiliki pengetahuan dan kepatuhan tentang APD. Menurut informasi dari pasien beberapa tenaga kesehatan yang ada di Puskesmas Ratahan tidak mematuhi prosedur Covid-19 tentang penggunaan APD, dan masih banyak tenaga kesehatan yang melayani pasien tidak memakai masker. Total kasus tenaga kesehatan terpapar Covid-19 di Puskesmas Ratahan pada Minggu, 15 Februari 2021 tercatat sembilan jiwa yang terkonfirmasi positif; tujuh di antaranya sembuh dan dua masih dalam perawatan. Bahkan dilaporkan Puskesmas Ratahan sempat ditutup sementara akibat meningkatnya angka terkonfirmasi positif dari tenaga kesehatan di Puskesmas Ratahan. Menurut satgas Covid-19 di Sulawesi Utara, Kabupaten Minahasa Tenggara termasuk risiko Covid-19 sedang.

Mengingat pentingnya peran penggu- 
naan APD dalam memutuskan rantai penularan Covid-19 dan survei awal di Puskesmas Ratahan maka penulis terdorong untuk meneliti pengaruh promosi kesehatan secara audio-visual terhadap pengetahuan penggunaan APD pada tenaga kesehatan di Puskesmas Ratahan Kabupaten Minahasa Tenggara.

\section{METODE PENELITIAN}

Penelitian ini dilaksanakan di Puskesmas Ratahan Kabupaten Minahasa Tenggara pada bulan Mei-Agustus 2021 dengan populasi total yaitu 40 responden. Jenis penelitian ini ialah pre-eksperimental dengan one-grup pre test post test design. Pada penelitian ini tidak terdapat kelompok pembanding (kontrol), tetapi paling tidak sudah dilakukan obervasi pertama (pre test) yang memungkinkan menguji perubahan yang terjadi setelah adanya eksperimen. Variabel penelitian terdiri dari variabel bebas yaitu promosi kesehatan tentang penggunaan APD Covid-19 dan variabel terikat yaitu pengetahuan tenaga kesehatan.

Kegiatan dimulai dengan menandatangani persetujuan pengisian kuesioner pretest kemudian dilakukan intervensi promosi kesehatan menggunakan audiovisual, dan dilanjutkan dengan pengisian kuesioner posttest. Analisis data dilakukan dengan menggunakan analisis univariat dan analisis bivariat dengan uji paired t-test.

\section{HASIL PENELITIAN}

Hasil penelitian mendapatkan 40 tenaga kesehatan yang berada di lokasi penelitian dan bersedia menjadi responden. Tabel 1 memperlihatkan distribusi responden berdasarkan karakteristik. Sebagian besar responden penelitian ini berjenis kelamin perempuan (95\%), usia dewasa awal (47,5\%), dan lama kerja di Puskesmas Ratahan yaitu 0-10 tahun (82,5\%).

Tabel 1. Distribusi responden berdasarkan karakteristik

\begin{tabular}{lcc}
\hline Karakteristik responden & $\mathbf{N}$ & $\mathbf{\%}$ \\
\hline Jenis kelamin & 2 & 5 \\
$\quad$ Laki-laki & 38 & 95 \\
$\quad$ Perempuan & 2 & 5 \\
Usia & 19 & 47.5 \\
Remaja ahir (17-25 tahun) & 3 & 7.5 \\
Dewasa awal (26-35 tahun) & 16 & 40 \\
Dewasa akhir (36-45 tahun) & & \\
Lansia awal (46-55 tahun) & 33 & 82.5 \\
Lama Kerja & 7 & 17.5 \\
0-10 tahun & 3 & \\
11-20 tahun & 20 & 7.5 \\
Tingkat Pendidikan & 12 & 50 \\
SLTA & 5 & 30 \\
Diploma III (DIII) & & 12 \\
S1 & 5 & 12.5 \\
Ners & 18 & 45 \\
Profesi & 11 & 27.5 \\
Dokter & 3 & 7.5 \\
Perawat & 1 & 2,5 \\
Bidan & 2 & 5 \\
Kesehatan Lingkungan & & \\
Perawat Gigi & 24 & 60 \\
Asisten Farmasi & 16 & 40 \\
Status Kepegawain & & \\
Pegawai Negeri Sipil (PNS) & & \\
Tenaga Harian Lepas (THL) & & \\
\hline
\end{tabular}


Tingkat pendidikan sebagian besar responden yaitu pendidikan Diploma III (DIII) $(50 \%)$, berprofesi sebagai perawat $(45 \%)$ dengan status kepegawaian PNS (60\%).

Tabel 2 memperlihatkan bahwa sebelum diberikan promosi kesehatan tentang APD Covid-19, pengetahuan tenaga kesehatan paling banyak berada pada kategori kurang yaitu 35 orang $(87,5 \%)$. Setelah diberikan promosi kesehatan tentang APD Covid-19 pengetahuan tenaga kesehatan meningkat pada kategori baik yaitu 36 orang (90\%). Setelah diberikan promosi kesehatan tentang APD Covid-19 yang kedua, pengetahuan tenaga kesehatan sudah mencapai kategori baik sebesar $100 \%$.

Analisis bivariat dilakukan dengan menggunakan uji paired t-test. Tabel 3 memperlihatkan bahwa nilai rerata pengetahuan tenaga kesehatan sebelum diberikan promosi kesehatan tentang penggunaan APD yaitu 22,48 dengan SD 1,5. Setelah pelatihan penggunaan APD rerata pengetahuan tenaga kesehatan menjadi 34,0 dengan SD 0,0. Hasil uji lebih lanjut mengenai pengaruh promosi kesehatan terhadap pengetahuan tentang kepatuhan penggunaan APD mendapatkan nilai $p=0,000(\alpha=0,05)$.

\section{BAHASAN}

Karakteristik reponden dalam peneli- tian ini yaitu tenaga kesehatan yang bekerja di Puskesmas Ratahan Kabupaten Minahasa Tenggara. Jumlah responden penelitian ini ialah 40 orang, jenis kelamin perempuan lebih banyak daripada laki-laki (38 vs 2). Menurut Apriluana et al, ${ }^{8}$ tidak terdapat hubungan bermakna antara jenis kelamin dengan perilaku pencegahan infeksi pada tenaga kesehatan. Apapun jenis kelaminnya tidak memengaruhi perilaku pencegahan infeksi. Jenis kelamin laki-laki maupun perempuan memiliki kesempatan yang sama untuk menerapkan perilaku pencegahan infeksi Covid-19 di tempat kerja masingmasing. Karakteristik reponden berdasarkan usia menurut Departemen Kesehatan ${ }^{9}$ terdiri dari remaja akhir berusia 17-25 tahun sebanyak dua orang (5\%); dewasa awal berusia 26-35 tahun sebanyak 19 orang $(47,5 \%)$; dewasa akhir berusia 36-45 tahun sebanyak tiga orang $(7,5 \%)$; dan lansia awal berusia 46-55 tahun sebanyak 16 orang (40\%). Usia merupakan salah satu karakteristik utama yang dimiliki, dan mempunyai hubungan erat dengan sikap dan sifat seseorang. ${ }^{9}$

Menurut Pasaribu, ${ }^{10}$ perilaku seseorang tidak hanya dapat ditentukan oleh usia tetapi juga didorong oleh motivasi individu tersebut untuk melakukan perilaku yang baik. Pada usia berapapun jika seorang sudah mempunyai dorongan kuat dalam dirinya maka perilaku yang baik akan terwujud.

Tabel 2. Distribusi frekuensi pengetahuan tenaga kesehatan sebelum dan sesudah diberikan promosi kesehatan APD COVID-19

\begin{tabular}{lcccccccc}
$\begin{array}{c}\text { Pengetahuan } \\
\text { tenaga kesehatan }\end{array}$ & \multicolumn{2}{c}{ Baik } & \multicolumn{2}{c}{ Cukup } & \multicolumn{2}{c}{ Kurang } & \multicolumn{2}{c}{ Total } \\
& $\mathrm{N}$ & $\%$ & $\mathrm{~N}$ & $\%$ & $\mathrm{~N}$ & $\%$ & $\mathrm{~N}$ & $\%$ \\
\hline Pretest & 0 & 0 & 5 & 15,5 & 35 & 87,5 & 40 & 100 \\
Posttest 1 & 36 & 90 & 4 & 10 & 0 & 0 & 40 & 100 \\
Posttest 2 & 40 & 100 & 0 & 0 & 0 & 0 & 40 & 100 \\
\hline
\end{tabular}

Tabel 3. Analisis pengaruh promosi kesehatan dengan audiovisual terhadap pengetahuan tentang APD COVID-19 pada tenaga kesehatan

\begin{tabular}{lccc}
\hline \multicolumn{1}{c}{$\begin{array}{c}\text { Pengetahuan Tenaga } \\
\text { Kesehatan }\end{array}$} & Mean & SD & Nilai p \\
\hline Pretest & 22,48 & 1,5 & \\
Posttest 2 & 34,0 & 0,0 & 0,000 \\
\hline
\end{tabular}


Pada karakreristik responden berdasarkan masa kerja petugas kesehatan, sebagian besar reponden bekerja selama $<10$ tahun yaitu sebanyak 33 responden $(82,5 \%)$ sedangkan yang telah bekerja $>10$ tahun sebanyak tujuh reponden $(17,5 \%)$. Hal ini menunjukkan bahwa sebagian besar tenaga kesehatan yang bekerja di Puskesmas Ratahan memiliki masa kerja yang cukup lama.

Pendidikan merupakan salah satu faktor penunjang kinerja tenaga kesehatan. Berdasarkan hasil penelitian yang dilakukan sebagian besar responden penelitian ini berada pada tingkat pendidikan Perawat Diploma III yaitu sebanyak 20 responden (50\%), dan paling sedikit berada pada tingkat pendidikan SLTA sebanyak tiga responden $(7,5 \%)$.

Profesi merupakan suatu pekerjaan yang mengandalkan ketrampilan atau keahlian khusus. Pada penelitian ini didapatkan kategori Dokter sebanyak lima responden $(12,5 \%)$, perawat sebanyak 18 responden $(45 \%)$, bidan sebanyak 11 responden $(27,5 \%)$, kesehatan lingkungan sebanyak satu responden $(2,5 \%)$, perawat gigi sebanyak satu responden $(2,5 \%)$, dan asisten farmasi sebanyak dua responden (5\%). Hal ini menunjukkan bahwa karaktersitik tenaga kesehatan di Puskesmas Ratahan berdasarkan profesi sebagian besar sebagai perawat.

Status kepegawaian dibedakan menjadi pegawai tetap dan tidak tetap. Hasil penelitian ini mendapatkan Pegawai Negeri Sipil (PNS) sebanyak 24 responden $(60 \%)$ dan Tenaga Harian Lepas (THL) sebanyak 16 responden $(40 \%)$.

Pengetahuan merupakan salah satu faktor predisposisi yang mempermudah terjadinya perilaku seseorang. Teori ini menjelaskan bahwa pengetahuan merupakan domain yang sangat penting untuk membentuk tindakan atau perilaku seseorang. Perilaku yang didasari pengetahuan akan lebih langgeng dibandingkan dengan perilaku yang tidak didasari pengetahuan. ${ }^{11,12}$ Pengetahuan seseorang diperoleh dari informasi, dan bila penerimaan informasi kurang maka pengetahuan yang diperoleh juga kurang. Pada penelitian ini pengetahuan responden sebelum promosi kesehatan tentang penggunaan APD Covid-19 pada 40 responden dengan persentase tertinggi pada kategori kurang yaitu sebanyak 35 tenaga kesehatan $(87,5 \%)$ yang menunjukkan sebagian besar responden sebelum diberikan pelatihan memiliki pengetahuan kurang.

Pada penelitian ini, pemberian promosi kesehatan pada tenaga kesehatan sangat penting, karena dengan adanya promosi kesehatan maka tenaga kesehatan akan memiliki peningkatan pengetahuan yang baik terhadap penggunaan APD Covid -19. Terdapat beberapa responden yang diberikan promosi kesehatan lewat audiovisual berulang kali sampai mencapai hasil $100 \%$. Hal ini sesuai dengan penelitian oleh Afandi ${ }^{13}$ yang melaporkan bahwa pengetahuan tenaga kesehatan yang baik terhadap perilaku penggunaan APD sebanyak 91 responden $(71,7 \%$,), dan pengetahuan tenaga kesehatan yang sedang terhadap perilaku penggunaan APD sebanyak 17 responden $(13,4 \%)$. Pengetahuan yang baik akan memengaruhi perilaku seseorang untuk berperilaku baik juga, karena proses tahu pada seseorang dapat dipengaruhi oleh faktor internal dan eksternal. ${ }^{13}$ Studi pendahuluan oleh Pangastuti ${ }^{7}$ terhadap responden tenaga kesehatan di RS PKU Muhammadiyah Yogyakarta Unit II juga mendapatkan hasil sangat baik. Pada variabel kepatuhan diperoleh sebanyak 21 tenaga kesehatan $(70 \%)$ patuh, dan 9 tenaga kesehatan $(30 \%)$ tidak patuh. Hal ini berarti bahwa kepatuhan tenaga kesehatan tentang pengunaan APD di RS PKU Muhammadiyah Yogyakartas Unit II sebagian besar ialah patuh. Marlina ${ }^{14}$ melakukan penelitian di Kantor Kesehatan Makassar dengan menggunakan rancangan survei deskriptif dan teknik pengambilan sampel secara total sampling sebanyak 54 petugas kesehatan. Sebagian besar petugas kesehatan patuh $(92,6 \%)$ menggunakan APD dalam pelaksanaan pencegahan Covid19; sebagian besar menggunakan sarung tangan (94,4\%); semua menggunakan masker (100\%); lebih dari setengah menggunakan penutup kepala $(63,3 \%)$; setengah menggunakan kacamata pelindung $(70,4 \%)$; dan lebih dari setengah menggunakan baju pelindung $(70,4 \%)$. Dalam penelitian tersebut terdapat pengaruh dalam pemberian 
promosi kesehatan kepada tenaga kesehatan. Hal ini juga selaras dengan penelitian oleh Fajrah ${ }^{15}$ mengenai pengetahuan dan sikap perawat tentang penggunaan APD di Puskesmas Sausa Kabupaten Parigi Mountong. Pada hasil analisis univariat didapatkan persentase responden berpengetahuan baik tentang penggunaan APD sebesar 90\%, sedangkan yang berpengetahuan cukup sebesar $10 \%$. Sikap tenaga kesehatan yang baik terhadap perilaku penggunaan APD sebanyak 87 responden $(68,5 \%)$, dan sikap tenaga kesehatan yang sedang terhadap perilaku penggunaan APD sebanyak 21 reponden $(16,5 \%) .^{15}$ Menurut Aditya, ${ }^{16}$ peningkatan penggunaan APD di saat pandemi menjadikan pengetahuan perawat tentang penggunaan APD sangat penting. Tingkat pengetahuan perawat tentang penggunaan APD selama menangani pasien Covid-19 yaitu sebanyak 37 perawat memiliki pengetahuan yang baik $(77 \%)$ dan 11 perawat memiliki pengetahuan yang cukup $(23 \%)$. Peningkatan pengetahuan tenaga kesehatan terjadi ketika mereka diberikan promosi kesehatan tentang APD Covid -19 yang dipaparkan melalui media. Pada penelitian ini setelah diberikan promosi kesehatan persentase tertinggi pada kategori baik yaitu sebanyak 40 tenaga kesehatan dengan presentase $100 \%$. Hal ini berarti setelah diberikan promosi kesehatan tentang penggunaan APD Covid-19 pengetahuan responden mengalami peningkatan.

Menurut hasil penelitian Devianty, ${ }^{17}$ tingkat pengetahuan dan kepatuhan tenaga kesehatan di RSKD saat pemakaian selama penggunaan APD, maupun pelepasan APD masuk dalam kategori baik. Hasil penelitian ini juga sejalan dengan penelitian megenai Covid-19 pada tenaga kesehatan di Nepal oleh Nepal et al $^{18}$ dan di Pakistan oleh Saqlain et al $^{19}$ yang menyatakan bahwa terdapat hubungan bermakna antara tingkat pengetahuan dengan perilaku.

Adanya peningkatan pengetahuan tenaga kesehatan sesunguhnya tidak lepas dari pemberian promosi kesehatan tetapi masih terdapat beberapa tenaga kesehatan yang memiliki pengetahuan kurang karena faktor usia yang sudah mendekati lanjut usia dan kurangnya pengetahuan bersosial media. Berdasarkan hasil penelitian ini, diketahui bahwa penelitian promosi kesehatan tentang penggunaan APD Covid-19 yang diberikan kepada tenaga kesehatan memiliki hasil positif karena penelitian ini memberikan pengaruh pengetahuan kepada tenaga kesehatan yang berada di Puskesmas Ratahan.

Hasil penelitian ini tidak sejalan dengan penelitian Ningsih ${ }^{4}$ terhadap tenaga kesehatan di Ruang Rawat Inap Rumah Sakit Umum Daerah Kota 46 Universitas Muhammadiyah Palembang Bandung yang melaporkan bahwa perilaku penggunaan APD tenaga kesehatan tidak bermakna dengan 52,4\% responden memiliki perilaku penggunaan APD yang kurang patuh. Demikian pula dengan hasil penelitian Siburian ${ }^{20}$ mengenai penggunaan APD pada perawat IGD RSUD Pasar Rebo yang masih dikategorikan kurang dalam pelaksanaan dan penerapannya. Hasil penelitian Pasaribu ${ }^{10}$ menunjukkan bahwa tidak terdapat kecenderungan responden yang memiliki pengetahuan baik mengenai Covid-19 akan memiliki perilaku pencegahan infeksi yang baik atau responden dengan pengetahuan kurang baik mengenai Covid-19 akan memiliki perilaku pencegahan infeksi yang kurang baik. Di Kota Medan, responden yang memiliki perilaku baik lebih banyak yang memiliki pengetahuan kurang baik $(75,2 \%)$, sedangkan responden yang memiliki perilaku kurang baik lebih banyak yang memiliki pengetahuan kurang baik (92,9\%). Di Kota Batam, responden yang memiliki pengetahuan baik lebih banyak yang memiliki pengetahuan baik $(77,3 \%)$, sedangkan responden yang memiliki pengetahuan kurang baik lebih banyak yang memiliki pengetahuan kurang baik $(38,5 \%)$. Tenaga kesehatan dan non-kesehatan yang berpengetahuan baik maupun kurang baik memiliki persentase yang hampir sama besar untuk berperilaku baik. Penelitian oleh Putra $^{21}$ pada mahasiswa profesi keperawatan di Universitas Indonesia menyatakan bahwa tidak didapatkan hubungan bermakna antara tingkat penegetahuan dan perilaku pencegahan infeksi dalam hal penggunaan APD. Dalam penelitian ini juga dijelaskan 
bahwa terdapat faktor lain selain pengetahuan yang dapat memengaruhi perilaku pencegahan infeksi saat bekerja di Puskesmas selama pandemi Covid-19. ${ }^{22}$ Putri $^{22}$ melakukan analisis faktor yang berhubungan dengan kepatuhan menggunakan APD pada karyawan PT Liku Telaga Gresik dan mendapatkan bahwa pendidikan dan sikap terhadap kebijakan sebagai faktor yang berhubungan bermakna dengan kepatuhan menggunakan APD dan memiliki kuat hubungan rendah. Dari hasil tesebut penulis berasumsi bahwa sebagian besar tenaga kesehatan dan non-kesehatan memang telah memiliki pengetahuan namun pada kenyataan pengetahun yang baik tidak menjamin bahwa tenaga kesehatan dan non-kesehatan akan memiliki perilaku pencegahan infeksi yang baik juga saat mereka bekerja di Puskesmas selama pandemi Covid-19.

Hasil uji t-test independent pengetahuan pada tenaga kesehatan menunjukkan nilai $p=0,000$ yang berarti terdapat pengaruh pelatihan penggunaan APD pada tenaga kesehatan di Puskesmas Ratahan. Penelitian ini menunjukkan terdapat peningkatan pengetahuan dengan diberikan promosi kesehatan penggunaan APD Covid-19 yang berpengaruh terhadap peningkatan pengetahuan individu. Rizqullah ${ }^{23}$ meneliti karyawan Rumah Sakit Muhammadiyah Palembang (RSMP) dan melaporkan bahwa persentase responden yang menggunakan APD tingkat 1 sebanyak 53,1\% (86 responden); APD tingkat 2 sebanyak 15,4\% (25 responden); dan APD tingkat 3 sebanyak $31,5 \%$ (51 responden). Persentase karyawan RSMP yang mengalami gejala klinis Covid-19 pada responden yang menggunakan APD tingkat 1 sebanyak 34,9\% (30 responden); responden yang menggunakan APD tingkat 2 sebanyak $56 \%$ (14 responden); dan responden yang menggunakan APD tingkat 3 sebanyak $17,6 \%$ (9 responden); hal ini menunjukkan terdapatnya pengaruh pengetahuan pemakaian APD lengkap pada karyawan di RSMP.

Menurut Atmodiwirio, ${ }^{24}$ pemberian promosi kesehatan atau pelatihan merupakan kegiatan yang didesain untuk membantu tenaga kerja memperoleh pengetahuan serta meningkatkan sikap dan perilaku untuk melaksanakan pekerjaan yang baik. Bila seluruh tenaga kesehatan diberikan promosi kesehatan atau pelatihan, besar kemungkinan bahwa kinerja tenaga kesehatan dalam pencegahan dan pengendalian Covid-19 akan menjadi sangat baik.

\section{SIMPULAN}

Promosi kesehatan tentang penggunaan APD berpengaruh secara bermakna dalam meningkatkan pengetahuan tenaga kesehatan. Pengetahuan tenaga kesehatan sebelum diberikan promosi kesehatan penggunaan APD umumnya masih kurang, dan setelah diberikan promosi kesehatan umumnya berada pada katagori baik.

Disarankan bagi Puskesmas Ratahan agar memperhatikan pemakaian APD pada tenanga kesehatan sesuai aturan yang telah dianjurkan. Diharapkan hasil penelitian ini dapat menjadi salah satu bahan referensi pendamping untuk peneliti selanjutnya.

\section{DAFTAR PUSTAKA}

1. Yuliana Y. Corona virus diseases. Jurnal of Wellness and Healthy. 2020;2(1):187-92.

2. Li Q, Guan X, Wu P, Wang X, Zhou L, Tong Y, et al. Early transmission dynamics in Wuhan, China, of novel coronavirusinfected pneumonia. NEJM. 2020; 382(13):1199-207. Doi: https://doi.org/ 10.1056/NEJMoa 2001316

3. Tandra H. Virus Corona Baru Covid-19, Yogyakarta: Rapha Publishing; 2020.

4. Ningsih SSR. Gambaran perilaku perawat dalam penggunaan alat pelindung diri di Ruang Rawat Inap Rumah Sakit Umum Daerah Kota 46 Universitas Muhammadiyah Palembang Bandung [Tesis]. Bandung: Universitas Pendidikan Indonesia; 2014. [cited 2020 Aug 28]. Available from: http://repository.upi. edu/ 15871

5. Sohrabi C, Alsafi Z, O’Neill N, Khan M, kerwan A, Al-Jabir A, et al. World Health Organization declares global emergency: a review of the 2019 novel corona virus (COVID-19). Int J Surg. 2020;76:71-6.

6. BBC News. 2021. Indonesia mencapai setengah juta kasus positif. Online Covid-19 Indonesia mencapai setengah juta kasus positif, 25\% di antaranya ada di Jakarta - 
BBC News Indonesia. Avialable from: bbc.com/Indonesia/Indonesia-51850113

7. Pangastuti EM. Evaluasi kepatuhan penggunaan alat pelindung diri (APD) pada perawat di RS PKU Muhammadiyah Yogyakarta Unit II [Karya Tulis Ilmiah Strata Satu]. Yogyakarta: Universitas Muhammadiyah Yogyakarta; 2014.

8. Apriluana G, Khairiaty L, Setyaningrum R. Hubungan antara usia, jenis kelamin, lama kerja, pengetahuan, dan sikap ketersediaan alat pelindung diri (APD) dengan perilku penggunaan APD pada tenaga kesehatan. Journal Publikasi Kesehatan Masyarakat Indonesia (JPKMI). 2016;3(3):82-7.

9. Departemen Tenaga Kesehatan RI. 2013. Riset kesehatan dasar tentang usia badan penelitian dan pengembangan kesehatan Kementerian Kesehatan RI. Available from: https://pusdatin.kemkes.go.id/ resources/download/general/Hasil\%20 Riskesdas\%202013.pdf

10. Pasaribu HKF. Hubungan antara pengetahuan dan sikap mengenai COVID-19 dengan perilaku pencegahan infeksi saat bekerja pada tenaga kesehatan dan nonkesehatan di puskesmas di zona merah di Kota Medan dan Kota Batam selama pandemi COVID-19 [Skripsi]. Medan: Univeristas Sumatera Utara; 2021.

11. Notoadmodjo S. Promosi Kesehatan dan Perilaku Kesehatan. Jakarta: Rineke Cipta; 2012.

12. Azwar. Sikap Manusia: Teori dan Pengukurannya. Yogyakarta: Pustaka Belajar; 2011.

13. Afandi A. Hubungan pengetahuan dan sikap tenaga kesehatan dengan perilaku penggunaan alat pelindung diri di masa pandemi COVID-19 di RSD Balung [Skripsi]. Jember: Universitas Muhammadiyah Jember; 2020.

14. Marlina R. Analisis kepatuhan penggunaan alat pelindung diri (APD) dalam pelaksanaan cegah tangkal penyakit covid-19 di pintu negara pada negara pada petugas kesehatan kantor pelayanan pelabuhan kelas 1 Makassar [Skripsi]. Makassar: Universitas Hasanuddin; 2020.

15. Fajrah S. Pengetahuan dan sikap perawat tentang penggunaan alat pelindung diri (APD) di Puskesmas Sausa Kabupaten Parigi Mountong. Jurnal Ilmiah Kesmas
IJ (Indonesia Jaya). 2019;19(1):1-8.

16. Aditya $\mathrm{H}$. Analisis pengetahuan perawat tentang penggunaan alat pelindung diri khusus untuk menangani pasien coronavirus disease 19 di Rumah Sakit Universitas Sebelas Maret 2020. Surakarta: Universitas Muhammadiyah Surakarta; 2020.

17. Deviyanti S. Evaluasi pengatahuan dan kepatuhan perawat dalam penggunaan alat pelindung diri (APD) selama pandemi COVID-19 di Rumah Sakit Khusus Daerah Dadi [Skripsi]. Makassar: Universitas Hassanudin; 2021.

18. Nepal R, Sapkota K, Paudel P, Adhikari B, Adhikari K, Saplota K, et al. (2020). Knowledge, attitude and a practice regarding COVID-19 among health care workers in Chitwan, Nepal. Journal of Chitwan Medical College. 2020;10(3): 98-102.

19. Saqlain M, Munir MM, Rehman SU, Gulzar A, Naz S, Ahmed Z, et al. Knowledge, attitude practice and perceived barriers among healthcare workers regarding COVID-19: a cross-sectional survey from Pakistan. J Hosp Inf. 2020;105(3): 419-23.

20. Siburian A. Gambaran penggunaan alat pelindung diri (APD) terhadap keselamatan kerja perawat IGD RSUD Pasar Rebo tahun 2012 [Skripsi]. Jakarta: Universitas Indonesia; 2012.

21. Putra UK. Hubungan tingkat pengetahuan, sikap dengan perilaku penggunaan alat pelindung diri pad mahasiswa profesi Fakultas Ilmu Keperawatan Universitas Indonesia [Skripsi]. Jakarta: Universitas Indonesia; 2012.

22. Putri KDS. Analisis faktor yang berhubungan dengan kepatuhan menggunakan alat pelindung diri. The Indonesian Journal of Occupation Safety and Health. 2017; 6(3):311-20.

23. Rizqullah A. Pengaruh pemakaian APD lengkap terhadap terjadinya gejala klinis COVID-19 pada karyawan di masa pandemi COVID-19 di RSMP [Skripsi]. Palembang: Universitas Muhammadiyah Palembang; 2020.

24. Amodiwirio. Manajemen Pelatihan (2nd ed). Jakarta: PT Pustaka Buletin Produktifitas, 2002. 